\title{
Teachers' and Students' Perspectives On Using Authentic Materials in Teaching English at Hanoi University of Home Affairs
}

\author{
Dinh Thị Huong, Ph.D \\ Hanoi University of Home Affairs, Vietnam \\ DOI: 10.29322/IJSRP.10.07.2020.p10375 \\ http://dx.doi.org/10.29322/IJSRP.10.07.2020.p10375
}

\begin{abstract}
Teaching materials play an important role in teaching and learning process. Authentic materials have proved useful in fulfilling the goal of communication of learning foreign languages and the needs of the learners. In addition, these materials facilitate and support the teaching and learning process. The purpose of this study is to (1) investigate teachers' and students' perceptions towards the advantages and challenges of authentic materials used in teaching English, and (2) explore the differences between teachers and learners' perspectives on authentic materials. Findings from the descriptive statistics were analyzed based on the questionnaire and semi-structure interviews. The results of the study suggested that general perspectives of the participants on authentic materials used in teaching English at Hanoi University of Home Affairs were positive.
\end{abstract}

Index Terms- perspective; authentic; material; language teaching; teaching materials

\section{INTRODUCTION}

$\mathrm{O}$ 1.1 Background of the study

ne of the most important and essential tools in foreign language teaching and learning is the material used during the lessons. The materials can have a significant effect on the language learners' motivation, learning process and desire to learn more. For this reason, the materials should be created from the learners' point of view since they are the ones who benefit the most from the materials. However, it must be pointed out that it is impossible to create materials that can meet the needs of language learners since the students are at different levels. As a result, a variety of different materials are used in foreign language teaching.

It is believed that using authentic materials correspond the mastery of four skills, enable students to function the language effectively in appropriate context and society. Epstein and Ormiston (2007) believe that a teaching material is a tangible factor that a teacher can use to deliver instruction and assist students in learning and acquiring a language.

McNeil (1994) and Kilickaya (2004) indicate that the use of authentic text is now considered to be one way for increasing students' motivation for learning since they give the learners the feeling that he/she is learning the real language - the target language as it is used by the community that speaks it.
It is true that when planning the materials for learning a foreign language, the opinions and thoughts of both teachers and students should naturally be taken into account since they know that what the best way to teach and learn is. The teachers and students are the ones who use the materials on a daily basis and know what works and what does not. In this study, the author took into account teachers' and students' perspectives and pointed out the differences between them to draw a reliable conclusion on the use of authentic materials in the foreign language classrooms.

\subsection{Aims of the study}

The study aims at investigating teachers' and students' perceptions towards the advantages and challenges of authentic materials used in teaching English, and exploring the differences between teachers and learners' perspectives on authentic materials.

\subsection{Research questions}

From the above mentioned aims, the study attempts to answer the following questions:

- What do teachers think of the benefits and challenges of authentic materials to students' learning?

- What do students think of the benefits and challenges of authentic materials to their learning?

- Is there a gap between teachers' and students' perspectives on authentic materials? What does the gap imply for classroom use of authentic materials?

\section{A REVIEW OF RELATED LITERATURE}

\subsection{Definitions of authentic materials}

According to Grave (2000), using materials is identified as one of the most important aspects in designing a language course. For this reason, teachers have variety of choices in choosing materials to support their teaching and students' learning.

Through the teaching and researching experience, many researchers have provided different definitions on authentic materials.

Nunan (1989) as cited in Adams (1995) believe that authentic materials as any materials that has not been specifically produced for the purpose of language teaching. Harmer (2001) stresses on the realness of certain materials by stating that authentic materials are those written for native speakers of the 
language with the real purpose. Similarly, Bacon and Finnemann (1990) define authentic materials as text produced by native speakers for non-pedagogical purposes. Gardner and Miller (1999) explain that authentic materials mean any texts (printed or digital) or tape which is produced for a purpose other than teaching the target language.

\subsection{Advantages of using authentic materials in teaching English}

Authentic materials are also interesting and motivating. By using authentic materials, learners can develop survival language skills and learn tolerance for regarding things they do not understand. Authentic materials are basically not produced for teaching or learning but give an exposure to language used in real life and when these materials are used in the classroom they motivate the learners to participate in a real conversation and thereby facilitate language learning.

It is evident that the uses of authentic text like newspapers helps the learner develop their communication skills and stimulate their interest in engaging them with the classroom activities through which they develop confidence and enjoy learning. Besides, learners are more comfortable when the input is provided from their own culture and customs in order to relate the context to the real life. Peacock (1997) and Brinton (1991) consider authentic materials as a bridge between the classroom and the real world, and offer the language learners a valuable source of authentic language input.

Moreover, this type of materials can also have an obvious effect on enhancing learners' motivation, arouse their interests and increase their active participation in learning activities. Tomlinson (2012) advocates that authentic materials can motivate learners and help them develop a range of communicative competencies and enhance positive attitudes towards the learning of a language. Similarly, Do (2011) finds that using authentic materials is an effectively way to enhance university students' motivation in foreign language courses. This idea is also true for teachers who have high motivation, and would like to implement new ideas in their classrooms. Teachers should be aware of their context and try to adapt things to meet students' needs.

\subsection{Challenges of using authentic materials in teaching English}

It cannot be denied that the advantages that authentic materials can bring is significant in getting learners exposed to the real use of the language, however there are still so many issues to consider.
Authentic input has long been perceived as too difficult for students at all levels. Martinez (2002) mentions that authentic materials may be too culturally biased and difficult to understand outside the language community. Learners may experience frustration "when confronted by an authentic text, especially lower level students as found by McNeil (1994). Schmidt (1994) argues that authentic discourse may panic learners who find themselves faced with the speech of delivery coupled with a mixture of known and unknown vocabulary and structures; instead, he prefers using simplified texts that have communicative value rather than using authentic input. Furthermore, grammar and vocabulary in authentic materials are used for communicating and informing in the society, thus the content of the text sometimes is not appropriate for students.

\section{METHODOLOGY}

\subsection{Participants}

93 third year students majoring in Human Resources Management and 5 full-time English teachers at Hanoi University of Home Affairs were selected to participate in the study. All the teachers had completed the Master degree in English Language Teaching Methodology. Their teaching experience ranged from six to fifteen years.

\subsection{Data collection instruments}

In order to collect data, questionnaire and semi-structured interview were used. The questionnaire was distributed to 93 students at Hanoi University of Home Affairs. The questionnaire included 10 items with a 4-point likert sclae from Strongly disagree (1) to Strongly agree (2) which was used to ask the learners to indicate their degree of agreement with the statement. Then, 5 full-time English teachers participated in semi-structured interview which was conducted and tape-recorded in order to transcribe for analysis. The semi-structured interview consists of 5 open-ended questions and lasted in 10 minutes.

\subsection{Procedures}

Quantitative and qualitative data analysis proceeded in two phases. In the first phase, the data obtained from the learners' questionnaires was analyzed using descriptive statistics with the SPSS program for calculating the total group mean scores and standard derivation. Later, the semi-structured interviews with teachers were analyzed using thematic analysis.

\section{FINDINGS AND DISCUSSIONS}

\subsection{Results from questionnaires for students}

\begin{tabular}{|c|c|c|c|c|c|c|c|c|c|c|}
\hline \multirow[t]{2}{*}{ Statements } & \multicolumn{2}{|c|}{$\begin{array}{l}\text { Strongly } \\
\text { disagree (1) }\end{array}$} & \multicolumn{2}{|c|}{$\begin{array}{l}\text { Disagree } \\
(2)\end{array}$} & \multicolumn{2}{|c|}{$\begin{array}{l}\text { Agree } \\
\text { (3) }\end{array}$} & \multicolumn{2}{|c|}{$\begin{array}{l}\text { Strongly } \\
\text { agree (4) }\end{array}$} & \multirow[t]{2}{*}{ Mean } & \multirow[t]{2}{*}{ Sd } \\
\hline & Freg. & $\%$ & Freg. & $\%$ & Freg. & $\%$ & Freg. & $\%$ & & \\
\hline \multicolumn{11}{|c|}{ Students' perspectives on the benefits of using authentic materials } \\
\hline $\begin{array}{l}\text { 1. Using authentic } \\
\text { materials help students } \\
\text { understand how English is } \\
\text { used in real life. }\end{array}$ & 1 & 1.1 & 6 & 6.5 & 55 & 59.1 & 31 & 33.3 & 3.25 & .620 \\
\hline $\begin{array}{l}2 . \quad \text { Using authentic } \\
\text { materials help students be }\end{array}$ & & & & & & & & & & \\
\hline
\end{tabular}




\begin{tabular}{|c|c|c|c|c|c|c|c|c|c|c|}
\hline $\begin{array}{l}\text { aware of the differences } \\
\text { between English in the } \\
\text { textbook and English in the } \\
\text { real life. }\end{array}$ & 1 & 1.1 & 11 & 11.8 & 50 & 53.8 & 31 & 33.3 & 3.19 & .680 \\
\hline $\begin{array}{l}\text { 3. The content of authentic } \\
\text { materials motivates } \\
\text { students. }\end{array}$ & 0 & 0.0 & 20 & 21.7 & 46 & 50.0 & 26 & 3.07 & 3.07 & .708 \\
\hline $\begin{array}{l}\text { 4. The cultural content in } \\
\text { authentic materials is } \\
\text { interesting. }\end{array}$ & 4 & 4.3 & 12 & 12.9 & 46 & 49.5 & 31 & 33.3 & 2.34 & .759 \\
\hline \multicolumn{11}{|c|}{ Students' perspectives on the challenges of using authentic materials } \\
\hline $\begin{array}{lrr}5 . \text { There are so many } \\
\text { unknown words } & \text { in } \\
\text { authentic materials. } & \end{array}$ & 9 & 9.7 & 50 & 53.8 & 27 & 29.0 & 7 & 7.5 & 3.18 & .691 \\
\hline $\begin{array}{l}\text { 6. The language in } \\
\text { authentic materials is too } \\
\text { difficult for students to } \\
\text { understand. }\end{array}$ & 2 & 2.2 & 9 & 9.7 & 52 & 55.9 & 30 & 32.3 & 3.12 & .792 \\
\hline \multicolumn{11}{|c|}{ Students' perspectives on how to use authentic materials } \\
\hline $\begin{array}{l}\text { 7. Authentic materials are } \\
\text { good for students whose } \\
\text { English is good. }\end{array}$ & 12 & 12.9 & 36 & 38.7 & 25 & 26.9 & 20 & 21.5 & 2.57 & .971 \\
\hline $\begin{array}{l}\text { 8. Authentic materials are } \\
\text { good only if teachers know } \\
\text { how to design appropriate } \\
\text { tasks. }\end{array}$ & 3 & 3.2 & 18 & 19.4 & 43 & 46.2 & 29 & 31.2 & 3.05 & .799 \\
\hline $\begin{array}{l}\text { 9. Authentic materials are } \\
\text { not necessary because there } \\
\text { is no time for students to } \\
\text { use them. }\end{array}$ & 56 & 60.2 & 36 & 38.7 & 1 & 1.1 & 0 & 0.0 & 1.41 & .516 \\
\hline $\begin{array}{l}\text { 10. Students should be } \\
\text { encouraged to bring } \\
\text { authentic materials into the } \\
\text { classroom to share with } \\
\text { other classmates. }\end{array}$ & 2 & 2.2 & 16 & 17.2 & 53 & 57.0 & 22 & 23.7 & 3.02 & .707 \\
\hline
\end{tabular}

Table 1: Students' perspectives on the benefits, the challenges of using authentic materials and how to use authentic materials

As can be seen from Table 1, the majority of the students (92.4\%) strongly agreed that authentic materials help them understand how English is used in the real life.

Similarly, in item 2 , most of the students $(87.1 \%)$ believed that using authentic materials help them be aware of the differences between English in the textbook and English in the real life.

For item 3, more than two thirds of the students $(78.3 \%)$ agreed that the contents of authentic materials are motivating.

In the next item, $82.8 \%$ of the students said that the cultural content in authentic materials is interesting while $17.2 \%$ of them felt that the materials are not intersting.

The responses to item 5 spread all over the four choices with different percentages. The biggest number of the students $(53.8 \%)$ disagree, and $9.7 \%$ of the students strongly agree that there are so many unknown words in authentic materials.

In terms of item 6 , nearly all the participants $(88.2 \%)$ found it difficult to understand the language in authentic materials, whereas $9.7 \%$ did not think it was too difficult to understand. Only $2.2 \%$ strongly disagree with this statement.

For item 7 , less than half of the students $(48.4 \%)$ agreeded that authentic materials are only good for students whose English is good. Meanwhile, $51.6 \%$ of the students had different points of view.

For the next item, item $8,77.4 \%$ of the respondents indicated that authentic materials are only good if teachers know how to design appropriate tasks.

In addition, in item 9, the majority of the students (98.9\%) did not believe that authentic materials are not necessary because there is no time for students to use them.

For item 10, most of the students $(81 \%)$ felt that they should be encouraged to bring authentic materials into the classroom to share with other classmate.

\subsection{Results from teachers' interviews}

The use of follow-up interview provided a more comprehensive picture of the participants' perspectives on authentic materials. The findings from the analysis are presented below.

\section{- Reasons for using authentic materials}


The results of the interviews indicated that four out of five teachers said that they used authentic materials for their own teaching purpose while one teacher replied that she did not use this kind of materials in her classes.

\section{- $\quad$ Frequency of the use of authentic materials}

Concerning about the frequency of the use of authentic materials, one teacher has reported before that she never uses authentic materials, the remaining four teachers ranged between 'Always' as indicated by two teachers, 'Often' by two teachers and 'Sometimes' by one.

\section{- Benefits of authentic materials in English language} teaching

It is obvious that all of the teachers perceived the advantages of authentic materials whether they

- Challenges of using authentic materials in the classroom All of teachers indicated that they have difficulties in using authentic materials in terms of time, the curriculum, the facilities for teaching, learners' background and attitude.

\section{- How to use authentic materials effectively}

Three out of five teachers said that they asked students collect and bring authentic materials that they like to class, so it was easy for teachers to engage students take part in activities in class. Two teachers shared that they selected the materials according to students' level, needs and interests.

\section{V.CONCLUSIONS}

The findings from the survey reveal that most of the teachers and students indicate positive attitudes toward providing authentic materials in their classes. Based on the responses in the students' questionnaire and teachers' semi-structured interview, it can be concluded that positive attitudes were grounded on many advantages of authentic materials in improving and developing language skills. Moreover, authentic materials have both positive effects on learners' motivation and bridge the gap between classroom setting and the everyday life language in the real world. Additionally, authentic materials provide learners authentic cultural information and support teachers a creative approach to teaching.

For better applications of authentic materials, English teachers should put more emphasis on the pedagogical purpose when selecting teaching resources. Appropriate authentic materials chosen can suit the students' language proficiency, and meet their interests and background. Besides, the government, through the Ministry of Education, should make a clear policy on the integration of media in education to provide an available access to authentic materials. Both students and teachers have chances to exploit the media for the use of authentic materials for teaching and learning language. As a result, universities have to be equipped with good facilities that support and provide teachers and students sources of authentic teaching and learning materials.

\section{REFERENCES}

[1] 1. Adam, T. (1995). What makes materials authentic? ERIC Document Reproduction. Service No. ED 391389

[2] 2. Bacon, S. M. \& Finnderman, M. D. (1990). A study of the attitudes, motives, and strategies of university foreign language students and their disposition to authentic oral and written input. The Modern Language Journal, 74(4), 459-473.

[3] 3. Briton, D. M. (1991). The use of media in language teaching: Teaching English as a Second or Foreign language. Boston: Heinle and Heinle Publisher.

[4] 4. Epstein, R. \& Ormiston, M. (2007). Tool and Tips for Using EFL Materials: A Guide for Teachers. MI: University of Michigan.

[5] 5. Do, Thi Thanh Tra. (2011). Using authentic materials to motive second year English major students at Tay Bac University during speaking lesson. Academic Network for Development in Asia Conference Proceedings.

[6] 6. Gardner, G. \& Miller, L. (1999). Establishing self-access: From theory to practice. Cambridge: Cambridge University Press.

[7] 7. Grave, K. (2000). Developing materials. Designing language courses: A guide for teachers. Boston, M.A: Heinle \& Heinle.

[8] 8. Harmer, J. (2001). The practice of English language teaching. London: Longman.

[9] 9. Kilickaya, F. (2004). Authentic materials and cultural content in EFL classrooms. The Internet TESL Journal, 10(7).

[10] 10. Martinez, A. (2002). Authentic materials: An overview. Karen's linguistic Issues.

[11] 11. McNeill, A. (1994). What make authentic materials different? Annual International Language in Education Conference Proceedings, Hongkong.

[12] 12. Peacock, M. (1997). The effect of authentic materials on the motivation of EFL learners. ELT Journal, 51(2), 144-156.

[13] 13. Schmidt, T. (1994). Authenticy in ESL: A study of requests. Unpublished M.A thesis. Southern Illinois University.

[14] 14. Tomlison, B. (2012). Materials development for language learning and teaching. Language Teaching, 45(2), 143-179.

\section{AUTHORS}

First Author - Dr. Dinh Thi Huong is currently a lecturer of English at Ha Noi University of Home Affairs. She earned her bachelor degree in English Language Teaching at Thai Nguyen University and the degree of Master of English majoring in TESOL at the Laguna University, The Philippines. She holds the degree of Ph.D in English Language and Literature at Batangas State University, The Philippines. Her interests include Translation Studies, Language Teaching for Children and Lexicology.

Email: dinhhuong.lilac@gmail.com 


\section{APPENDIX 1}

\section{STUDENTS QUESTIONNAIRE}

Authentic materials are texts produced by native speakers for non-teaching purposes. These materials reflect the real world. Such materials include TV commercial, news items, weather forecast, radio talks, interviews, articles, train timetables, advertisements, brochures, and application forms.

Please put a tick $(\checkmark)$ in the column that bets shows your level of agreement and disagreement.

\begin{tabular}{|c|c|c|c|c|c|}
\hline No. & Statements & $\begin{array}{l}\text { Strongly } \\
\text { disagree }\end{array}$ & Disagree & Agree & $\begin{array}{l}\text { Strongly } \\
\text { agree }\end{array}$ \\
\hline 1 & $\begin{array}{l}\text { Using authentic materials help students understand } \\
\text { how English is used in real life. }\end{array}$ & & & & \\
\hline 2 & $\begin{array}{l}\text { Using authentic materials help students be aware of } \\
\text { the differences between English in the textbook and } \\
\text { English in the real life. }\end{array}$ & & & & \\
\hline 3 & The content of authentic materials motivates students. & & & & \\
\hline 4 & $\begin{array}{l}\text { The cultural content in authentic materials is } \\
\text { interesting. }\end{array}$ & & & & \\
\hline 5 & $\begin{array}{l}\text { There are so many unknown words in authentic } \\
\text { materials. }\end{array}$ & & & & \\
\hline 6 & $\begin{array}{l}\text { The language in authentic materials is too difficult for } \\
\text { students to understand. }\end{array}$ & & & & \\
\hline 7 & $\begin{array}{l}\text { Authentic materials are good for students whose } \\
\text { English is good. }\end{array}$ & & & & \\
\hline 8 & $\begin{array}{l}\text { Authentic materials are good only if teachers know } \\
\text { how to design appropriate tasks. }\end{array}$ & & & & \\
\hline 9 & $\begin{array}{l}\text { Authentic materials are not necessary because there is } \\
\text { no time for students to use them. }\end{array}$ & & & & \\
\hline 10 & $\begin{array}{l}\text { Students should be encouraged to bring authentic } \\
\text { materials into the classroom to share with other } \\
\text { classmates. }\end{array}$ & & & & \\
\hline
\end{tabular}

Thank you!

\section{APPENDIX 2}

\section{QUESTIONS FOR TEACHERS' INTERVIEW}


1. What are the reasons for your using or not using authentic materials? How often do you use authentic materials?

2. In your opinion, what kinds of materials are considered as authentic materials? Give some examples.

3. If you have used authentic materials in your teaching, what do you think are the benefits to the students? Give examples.

4. What are the challenges of using authentic materials in the classroom? Give examples.

5. Can you give some suggestions to use authentic materials effectively? 